\title{
7
}

\section{Colonial Legacies in International Aid: Policy Priorities and Actor Constellations}

\author{
Bastian Becker
}

\section{Introduction}

In the past century, international aid has become an essential part of the foreign policy toolkit. It is especially popular among former colonial powers which spend the majority of their aid budgets on countries that once were part of their empires (Alesina and Dollar 2000; Fuchs et al. 2014; Round and Odedokun 2004; Steinwand 2015). However, beyond this general pattern, little more is known about the colonial legacy of international aid. This is unfortunate because recent migration movements have reinvigorated debates about historical responsibilities of European countries. In this chapter I argue that the organization of colonial empires shapes the ways in which former colonial powers provide aid

B. Becker $(\bowtie)$

SOCIUM Research Center on Inequality and Social Policy, University

of Bremen, Bremen, Germany

e-mail: Bastian.becker@uni-bremen.de

(C) The Author(s) 2020

C. Schmitt (ed.), From Colonialism to International Aid, Global Dynamics of Social

Policy, https://doi.org/10.1007/978-3-030-38200-1_7 
today, in particular policy priorities and actors involved in the distribution of aid. This claim is supported by analyses of newly available, highly disaggregated data on aid flows.

In this chapter I focus on the two largest and most recent colonial empires, those of Britain and France. ${ }^{1}$ These cases are also interesting as they employed different colonial strategies. Whereas Britain often relied on indirect rule, using existing political structures to project its power, France more commonly used direct rule, imposing new structures with less consideration for local conditions (Gerring et al. 2011; Iyer 2010; Mamdani 1996). Indirect rule also led Britain to more strongly involve other actors, be they local, non-governmental or international. France instead relied on the newly built governmental capacities, and bureaucratic centralization fostered close ties between the metropolitan and colonial governments (Lee and Schultz 2012; Schmitt 2015; Schmitt, Chap. 6, this volume). To facilitate their colonial undertakings (and to decelerate their demise), both powers also promoted social protection policies (see also Schmitt, Chap. 6, this volume). These efforts were especially pronounced in the French empire, due to the application of metropolitan law in colonies and the goal to assimilate subjugated populations (Iliffe 1987; Wesseling 2004). Path dependency, due to lasting economic, political and social ties, suggests that these differences should also be reflected in how Britain and France provide aid today.

Research on colonial legacies of international aid was until recently limited to the analysis of aggregate aid flows. However, newly available, highly disaggregated data makes it possible to analyze aid flows in greater detail (see OECD 2018a). This data allows me to show that colonial legacies are reflected in how former colonial powers distribute aid today. For example, both Britain and France focus aid to their former colonies on social protection, about 9 percentage points more than what they give to other countries. As expected, France strongly relies on governmental actors to channel aid to its former colonies (about 92\%), whereas Britain uses governmental channels for a mere $22 \%$ of all aid. These differences cannot be accounted for by common explanatory factors, such as economic development, trade openness or democracy. These findings have important

\footnotetext{
${ }^{1}$ Note that in most instances below, country names refer to the respective governments.
} 
implications for our understanding of international aid today. They emphasize that policy priorities and the actor constellations promoted by aid might be harder to change than often expected.

The chapter proceeds as follows. Section "Colonial Legacies in International Aid" introduces literature that informs our understanding of the colonial legacies of international aid, in particular concerning policy priorities and actor constellations. Section "Data" introduces the new aid data and other variables used in the analysis. Section "Analysis" presents the main results, followed by a final discussion in Sect. "Discussion".

\section{Colonial Legacies in International Aid}

It is well established that most donors provide more bilateral aid to former colonies than other recipient countries. This is certainly the case for the two former colonial powers this study focuses on, Britain and France. It is commonly argued that bilateral aid serves for maintaining political influence and economic relationships that developed during colonial times (Alesina and Dollar 2000; Berthélemy and Tichit 2004; Fuchs et al. 2014). However, not all scholars argue that self-interest determines aid disbursements to former colonies. Others point out that colonial powers increasingly assumed responsibility for the well-being of subjugated populations, due to growing cultural similarities (Schraeder et al. 1998) and deliberations among domestic and international political circles (Lewis 2011; Pacquement 2010).

Most comparative work on colonial legacies of international aid focuses on the overall generosity of donors toward former colonies. This chapter seeks to reveal in greater detail how colonial legacies unfold. Therefore, two aspects of contemporary international aid take the center stage. First, the extent to which donors prioritize social protection, promoting activities such as health and education; and second, the actors involved in the distribution of aid, in particular aid directed at social protection. As the review below shows, the existing literature suggests that colonial legacies are likely to become manifest in these regards. Other than that, this choice is arbitrary, and it is likely that colonial legacies affect international aid in many other ways. That said, focusing on policy priorities and aid actors offers a reasonable starting point for advancing knowledge about colonial legacies in international aid. 


\section{Policy Priorities: Social Protection}

Colonial empires were first and foremost economic undertakings. Their primary aim was to exploit colonized territories to the benefit of their metropoles. Colonial powers like Britain and France therefore initiated economic structures and re-shaped existing ones to best suit this purpose. This was achieved by aligning policies with the overarching aim of economic exploitation. With regard to social protection, this implied a minimalist approach that focused on attracting Europeans to the overseas territories and on retaining a viable labor force within the colonies. There was little interest in what goods were demanded locally. As a result, colonial economies focused on mining and agriculture, cash crops in particular, and unsurprisingly they were strongly export-oriented.

Social protection was also promoted for non-economic reasons, especially during later years. Colonial administrators were concerned about the well-being and social status of Europeans and, at least to some extent, about the well-being of the subjugated populations (Lewis 2011; Pacquement 2010). Basic social services for the indigenous population were furthermore needed to reduce labor scarcity prevalent in many colonies. Although unintended, migration in both directions led to a growing number of personal ties between metropole and colony, which increased the chances that social needs within the colonies were recognized and addressed (Lahiri and Raimondos-Møller 2000). Furthermore, after World War I international organizations became active in colonial politics and policy-making, urging colonial powers to take more and more responsibility for the situation in territories dependent on them (Pearson 2018).

While the British and the French colonial empires both had the primary aim of economic exploitation, they differed widely when it comes to specific policy areas. Social protection is no exception. British administrations rarely provided benefits to anyone but government workers. Other schemes were initiated only if pre-existing local arrangements would not suffice and, as I discuss further below, if no other external actor, like missions or firms, stepped in. Mirroring social protection policies at home, France provided benefits to a wider set of workers, 
including many of those in formal employment. More generally, France frequently extended metropolitan laws and rights to colonies, with the ultimate goal of assimilating subjugated populations (Iliffe 1987; Kpessa 2010). At the same time, France's interventionist approach often came at the expense of local practices and institutions, which were rarely promoted and often curtailed instead (Suret-Canale 1971).

Independence had little effect on the economic set-up of (former) colonies, in particular regarding sectoral composition and export orientation. Companies that previously enjoyed quasi-monopolistic positions lobbied for favorable trade agreements with former colonies and, where possible, continued their operations. They were supported by the former colonial powers which continued to shape and influence policy-making in the newly independent territories, for example by providing aid (Alesina and Dollar 2000; Fuchs et al. 2014). In fact, the provision of aid to advance trade interests is not limited to former colonies or the aftermath of independence but continues to be a wide-spread practice (Berthélemy and Tichit 2004; Schraeder et al. 1998). The consequence for former colonies is that many remain dependent on international markets and continue to have strong trade links with their former colonizers (Abernethy 2000; Cardoso and Faletto 1979).

Besides the promotion of trade interests, donors (including former colonial powers) often prioritize aid to countries where social needs go unaddressed. Several studies have shown that most aid goes to countries with high levels of economic poverty (Dollar and Levin 2006; Easterly and Pfutze 2008; Nunnenkamp and Thiele 2006), whereas others have demonstrated a focus on countries with poor health outcomes (Bodenstein and Kemmerling 2015; Boschini and Olofsgård 2007; Schraeder et al. 1998). Although these studies do not explore whether donors prioritize social needs of former colonies over those of other recipients, there are good reasons to suspect that this is the case. Donors might continue to be concerned about the welfare of formerly subjugated populations (Pacquement 2010), personal networks can put former colonies in politically advantageous positions (Lahiri and Raimondos-Møller 2000), and international organizations sustain pressure on donors to assume responsibility for territories they once ruled (Pearson 2018). 
Colonial powers promoted social protection for intrinsic and, more commonly, instrumental reasons. However, little is known about whether early investments in social protection of many of today's developing countries affect contemporary patterns of bilateral aid. While independence brought major changes with it, it is also clear that many political, economic and social ties have survived. It can be argued that this is also the reason why many former colonial powers continue to promote social protection. Thus, the first hypothesis I test in this chapter is that donors prioritize social protection when providing aid to former colonies or, to put it differently, that compared to other recipients larger shares of aid to former colonies are directed toward social protection. I have also argued that the French colonial government assumed a more interventionist role in matters of social protection than Britain did in its empire. Thus, the second hypothesis I explore is that the prioritization of social protection is especially pronounced in the case of French aid.

\section{Actor Constellations}

Colonialism is not a unitary phenomenon. Abernethy (2000) explains the rise of European colonial empires with the interplay of three decisive types of actors: governments, firms and missions. While these actors often had competing interests in Europe, their actions overseas proved highly synergetic. It is furthermore important to realize that each type of actor is internally split, consisting of an umbrella organization in the metropole and its representations abroad (Abernethy 2000). Beyond this basic set-up, important differences between colonial empires can be noted. The French empire followed a more centralized approach. This tied administrations in the colonies more closely to the French government and gave them less room to adjust laws and practices to local context (Lee and Schultz 2012; Schmitt 2015). Catholic France also had a more restrictive stance on the activities of Protestant missions. Instead, the British government early succumbed to lobbying by the British East India Company and allowed both Catholic and Protestant missions to operate within its territories (Woodberry 2012). 
A common conceptual distinction in scholarship on colonialism is that between direct and indirect rule (Gerring et al. 2011; Iyer 2010; Mamdani 1996). The two kinds of rule mainly distinguish how local political institutions and elites are incorporated into the colonial empire. Direct rule implies the imposition of new administrative structures that overwrite existing ones. Locals that assume positions in the new administration are usually not members of the former elite. To the contrary, indirect rule implies the installation of a new administration at the head of existing structures. While this also imposes a clear hierarchy, power is projected through existing structures and in collaboration with established local elites. Of course, this collaboration was not always voluntary and colonial administrators could, if they deemed it necessary, rely on military force and other more "collaborative" elites.

The French empire applied, with few exceptions, direct rule. The British Empire was mainly characterized by indirect rule. Direct rule in the French empire thus led to the establishment of governmental structures akin to those in mainland France. At the same time existing structures were dwarfed, placing greater relative weight on the new governing bodies. The dwarfing of existing structures was not limited to political institutions but included social and economic ones. This was often justified with ideas about "assimilation", which had the ultimate goal to extent French citizenship to colonial subjects (Wesseling 2004). The British government, instead, accepted local actors and institutions, and if it facilitated economic exploitation, even promoted them (Midgley 2011).

The degree of centralization, type of rule and assimilation strategies also had implications for the provision of social protection in colonies. As regards other local practices and institutions, French administrations ignored, or even worked against, social protection arrangements established before colonization. Local medical practices, which were decried as "witchcraft", are one such example (Suret-Canale 1971). Instead, colonial administrations in the French empire sought to transplant arrangements from the metropole to colonized territories. While social protection spread widely only in the 1950s, after the creation of the French Union, it covered a wide range of social needs, such as illness, 
maternity or work accidents (Iliffe 1987, 208). Due to the application of French law within colonized territories, social protection provided by the state often extended beyond government workers to also include workers in formal employment (Kpessa 2010).

British administrations were less committed to government-provided social protection. On the one hand, there was a high reliance on preexisting local arrangements, which were only to be complemented if changes induced by colonization gave rise to new needs, for example due to labor migration (Kpessa 2010; Midgley 2011). On the other hand, British administrations more strongly involved other external actors in the provision of social protection. As such, missions were encouraged to establish schools and hospitals and were called upon to address various social risks through the establishment of provident funds (Dixon 1989). For both empires it must be said that externally initiated initiativeswith the exception of missionary activities - were largely limited to Europeans and only gradually, if at all, extended to local populations. They were extended to local populations; this was usually done to protect the health and well-being of Europeans (Suret-Canale 1971; Wesseling 2004).

In the twentieth century, international organizations entered the field of social protection (Deacon 2007; Pedersen 2015). While their involvement represented an emerging Western-centric consensus on the global stage, colonial powers were frequently opposed to specific initiatives. This is especially true for the French government, which-more often than the British government-regarded the involvement of international organizations to be against its interests. Efforts by the International Labour Organization (ILO) to abolish forced labor are one example. Even a public condemnation of French activities in the Congo at the 12th ILO conference in 1929 had no discernible effect on practices within the empire (Suret-Canale 1971, 244-55). France eventually committed to the abolition of forced labor in its colonies in 1946, a step Britain had taken more than a decade earlier (Daughton 2013; Maul 2007). Similarly, France also perceived the expansion of UN organizations as a threat and opposed the establishment of representations in its colonies (e.g. a regional office of the World Health Organization in Africa). The founding of the French Union itself, which implied the inte- 
gration of colonies into French territory, can be seen as an attempt to countervail the mounting anticolonial pressures from international bodies (Pearson 2018).

The preceding discussion shows that the two colonial empires, Britain and France, relied on different sets of actors for organizing their colonial empires (see Shriwise, Chap. 2, this volume). Direct rule, a highly centralized bureaucracy and the assimilation strategy in the French empire implied a strong reliance on and promotion of governmental capacities. This also entailed closer institutional ties between the metropolitan government and colonial administrations in the dependent territories than was the case in the British Empire. The government in London not only gave colonial administrations greater leeway, it also collaborated more intensely with other actors. As a result, the British Empire relied relatively less on governmental capacities. Therefore, my third hypothesis concerns the involvement of governmental actors vis-à-vis other actors in the disbursement of bilateral aid: Relative to British aid, more French aid to former colonies is distributed through governmental channels (including the newly independent governments).

These differences between the empires are also found when it comes to social protection. While the French government took charge of activities such as education, health and pensions, the British government eagerly outsourced these activities to other actors, most notably missions, indigenous communities and firms. British authorities were also more likely to nurture ties with international organizations, whereas France often sought to shield itself from their influence. Whether relying on governmental capacities simply mirrors the general approach of the French government or is particularly pronounced with regard to social protection is an open question. To test this, hypothesis four states that the French reliance on governmental channels in distributing aid to former colonies is particularly pronounced with regard to social protection.

\section{Contribution}

Earlier research on aid determinants has shown that colonial legacies lead to greater donor generosity. However, I have argued that colonial legacies 
should also have an impact on what policy areas donors give aid to and on the actors that donor governments involve in the disbursement of aid. Until recently, these claims could not be tested comparatively, as aid data was only available in highly aggregated form. In the following, I draw on new disaggregated data that allows me to determine the distribution of aid across policy areas and actors. I test the four hypotheses developed above. First, the social protection share is higher with aid to former colonies than with aid to other countries. Second, the social protection share of aid to former colonies is especially pronounced for French aid. Third, a larger share of French aid to former colonies, in comparison to British aid, is disbursed through governmental channels. Fourth, the French reliance on governmental channels is particularly pronounced for aid directed at social protection in former colonies.

\section{Data}

Bilateral aid involves a donor and a recipient and thus constitutes a relational phenomenon. Therefore, the sample I analyze in the following consists of donor-recipient dyads, whereby bilateral aid flows between the two countries constitute the dependent variable. To avoid inducing biases through sample selection, it is important to consider all potential recipients, not only former colonies. Hence, I include all independent nation states, with the exception of high income countries, for which bilateral aid is virtually non-existent, into the sample. Put differently, the sample is composed of all pairs of low and middle income countries (LMICs) with each Britain and France. ${ }^{2}$ In the following analyses, donor identity is distinguished by a dummy variable, Donor: France, that takes value 1 if the dyad involves France and 0 if it involves Britain.

\footnotetext{
${ }^{2}$ According to the World Bank, whether a country belongs to the groups of LMICs is determined based on its per-capita GDP, and thus changes in the classification are possible over time. In line with the treatment of other variables (see below), I calculate each country's per-capita GDP (2011 US\$-PPP) by averaging over the five years preceding the CRS data, that is, 2003-2007. I then use the 2011 cut-off point of US \$12,195 (see https://datahelpdesk.worldbank.org/knowledgebase/ articles/906519-world-bank-country-and-lending-groups for details) to select the countries to be included in the LMIC sample.
} 
With the founding of the Development Assistance Committee (DAC), which includes most Organisation for Economic Co-operation and Development (OECD) member states, data on bilateral aid has been collected systematically and facilitated the comparative analysis of aid activities. While the data allows research to explore developments from as far back as 1960, only highly aggregated data was available to researchers. It was therefore not possible to distinguish different types of aid flows, leaving many questions unanswered. Is aid provided in the form of grants or loans? What policy areas does it go to? And who is involved in its distribution?

This situation changed with the introduction of the OECD Creditor Reporting System (CRS), which made highly disaggregated aid data publicly available. The CRS is composed of project-level data with information on individual aid agencies, types of finance, sectoral allocations and project descriptions. As such, the CRS allows researchers to address a much wider range of questions about international aid. One disadvantage of the new data is that it covers a much shorter period of time. Although the CRS was initiated in 1973, only data from 2007 onward is considered complete. As such, the CRS data is not as suitable for analyzing temporal developments as the more aggregated data. However, this carries no implications for the present chapter, as I am interested in cross-sectional differences. The CRS data is therefore ideally suited to exploring in how far contemporary bilateral aid reflects colonial legacies.

For the purposes of this chapter, I make use of the sectoral information the CRS provides in order to discern aid flows going toward the social sector, and thus social protection, from aid to other sectors. The three main sectors in the CRS data are "social infrastructure and services" (social sector), "economic infrastructure and services", and "production sectors". Other sectors include "multisector aid", "action relating to debt", and "humanitarian assistance". The OECD defines social sector aid as "efforts to develop the human resource potential and ameliorate living conditions in developing countries. It includes but is not limited to:

- Education: Educational infrastructure, services and investment in all areas. Specialised education in particular fields such as agriculture or energy is reported against the sector concerned. 
- Health and population: Assistance to hospitals and clinics, including specialised institutions such as those for tuberculosis, maternal and child care; other medical and dental services, including disease and epidemic control, vaccination programmes, nursing, provision of drugs, health demonstration, etc.; public health administration and medical insurance programmes; reproductive health and family planning.

- Water supply, sanitation and sewerage: All assistance given for water supply, use and sanitation, river development, but excluding irrigation systems for agriculture." (OECD 2018b, 10)

Furthermore, the CRS allows me to discern what actors are involved in the distribution of aid. Actors can be identified by relying on the information provided on delivery channels: "The channel of delivery is the first implementing partner. It is the entity that has implementing responsibility over the funds [...]" (OECD 2010, 8). The CRS distinguishes five delivery channels: "public sector institutions", "non-governmental organizations", "public-private partnerships", "multilateral organizations" and others. Public sector institutions include both donor and recipient governments as well as their agencies. It therefore enables me to distinguish aid that is distributed through governmental channels/actors from aid distributed in cooperation with other actors.

For each donor-recipient dyad, I calculate four indicators to characterize aid flows between them. ${ }^{3}$ First, I compute the total aid flow by summing over all projects in a given year. Second, I compute the social aid flow by summing only over projects aimed at social protection (i.e. social sector). Third and fourth, I compute, for total aid and social aid respectively, the share of aid disbursed through governmental channels. The computation is limited to aid provided as grants, which do not have to be repaid and therefore constitute a clear, unidirectional transfer. ${ }^{4}$ To avoid mistaking temporal fluctuations for cross-sectional differences, I compute each indicator for each complete year in the CRS data (2007-2016) and sub-

\footnotetext{
${ }^{3}$ Aid given by country donors to multilateral donors with defined recipient country, so-called bi-multi aid, is included in the calculation.

${ }^{4}$ Aid loans, which have to be repaid, are functionally and strategically distinct and are therefore excluded.
} 
sequently average them. The averages of each indicator are the dependent variables used in the following analyses.

When exploring in how far bilateral aid reflects colonial legacies, it is important to also account for other determinants of aid flows. Becker (2019) provides a comprehensive dataset on the geographic and temporal reach of all major European colonial empires. Based on the dataset, I determine the last colonizer for each country in my sample and create a dummy variable, colonial legacy, to indicate whether a given donorrecipient-dyad is characterized by a joint colonial history. As such, colonial legacy is a characteristic of the dyad, not of the recipient country. In addition, the following statistical analyses include a number of control variables. Unless pointed out otherwise, these variables are derived from the World Development Indicators (World Bank 2018). All numeric variables are calculated by averaging data across the five years preceding the bilateral aid data I use (2003-2007). This approach ensures that results are not affected by short-term fluctuations and also takes into account that aid strategies take time to adjust to changing conditions in recipient countries.

Economic interests play an important role in international politics, and when it comes to aid it is often suggested that donors are interested in opening up markets and securing preferential access for their own firms. I therefore include a trade openness variable which captures the amount of exports and imports as percentage of the recipient's GDP. Others contend that aid aims at promoting certain values and norms in recipient countries, in particular democracy. To determine whether donors reward democratic practices in recipient countries, I include the Freedom House (2018) political rights score as democracy variable into the analysis (original scores inverted for more intuitive interpretation). Most donors focus aid efforts on poor countries. This is commonly referred to as poverty focus. As many former colonies rank among the world's poorest countries, it is also possible that a poverty focus rather than the colonial legacy explains why former colonies receive more or specific types of aid. In line with earlier scholarship, I use per-capita income as a proxy for the level of poverty. Although income per capita would preferably be calculated based on gross national incomes, I rely on gross domestic products (US \$2011, PPP), due to greater data coverage. 
Table 7.1 Descriptives of donor-recipient aid flows

\begin{tabular}{lrrrrl}
\hline & Mean & \multicolumn{1}{c}{ Median } & \multicolumn{1}{c}{ Min } & \multicolumn{1}{c}{ Max } & NA\% \\
\hline Total aid & 28.30 & 2.14 & 0.00 & 381.26 & 0.00 \\
Social aid & 15.25 & 1.07 & 0.00 & 274.55 & 0.00 \\
Total aid (\% Gov.) & 47.82 & 51.73 & 0.00 & 100.00 & 0.00 \\
Social aid (\% Gov.) & 47.64 & 43.91 & 0.00 & 100.00 & 0.00 \\
GDP per capita & 4.87 & 3.86 & 0.55 & 12.15 & 0.00 \\
Population size & 39.72 & 7.12 & 0.01 & 1303.42 & 0.00 \\
Trade openness & 84.67 & 80.64 & 0.29 & 244.26 & 3.45 \\
Democracy & -3.91 & -3.80 & -1.00 & -7.00 & 0.86 \\
Colonial legacy & 0.29 & 0.00 & 0.00 & 1.00 & 0.00 \\
Africa & 0.41 & 0.00 & 0.00 & 1.00 & 0.00 \\
Americas & 0.18 & 0.00 & 0.00 & 1.00 & 0.00 \\
Asia & 0.24 & 0.00 & 0.00 & 1.00 & 0.00 \\
Europe & 0.08 & 0.00 & 0.00 & 1.00 & 0.00 \\
Oceania & 0.09 & 0.00 & 0.00 & 1.00 & 0.00 \\
Donor: France & 0.50 & 0.50 & 0.00 & 1.00 & 0.00 \\
\hline
\end{tabular}

Note: The sample units constitute donor-recipient dyads $(n=232)$. Income per capita in thousands, Trade openness in percentage of GDP, Population size and poverty headcount in millions. Colonial legacy according to Becker (2019), aid data based on OECD CRS, Democracy derived from Freedom House and all other data based on WDI

Furthermore, I control for population size and geographical region. Population size accounts for the frequent focus of international aid on large developing countries (McKinlay and Little 1979). Geographical region accounts for unobserved variation across continents, which might otherwise influence results. Table 7.1 displays descriptive statistics for all variables. For five recipient countries, and thus ten dyads, information on trade openness is missing; they are excluded from the following analysis.

\section{Analysis}

As this chapter is interested in the colonial legacies of contemporary international aid, it is informative to take a look at how aid flows to former colonies differ from flows to other countries. Therefore, Fig. 7.1 depicts total aid flows by donor (Britain, France, EU) and recipient (British colony, French colony, other). Information on aid from EU institutions is included as a reference point. However, as it can be observed, the aid patterns 

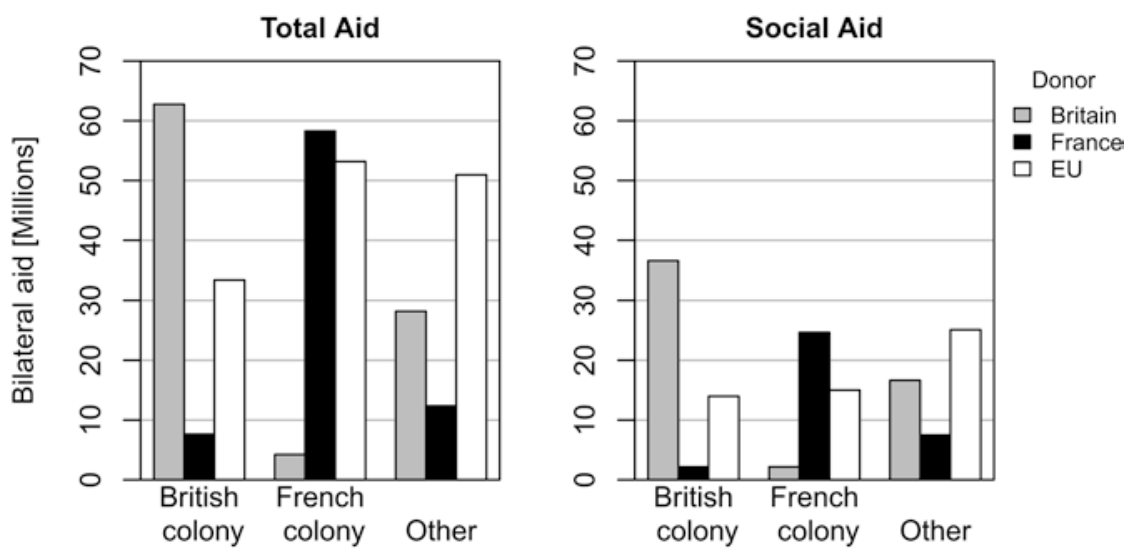

Fig. 7.1 Average annual aid flow by donor and colonial legacy, absolute disbursements (2007-2016)

of both former colonial powers differ sharply from that of EU spending. The left panel reproduces the conventional finding that former colonial powers strongly favor countries that used to be part of their respective empire. Both the 45 British colonies and the 22 French colonies in this sample received an annual average of almost US $\$ 60$ million aid in grants (between 2007 and 2016). Interestingly, both donors also provide particularly little aid to former colonies of the respectively other donor; they are more generous toward countries not colonized by either of them. The right panel shows how much aid is spent on social protection. For former colonies, a bit more than half of all British aid is spent on social protection, whereas this figure is slightly less than half for French aid.

This chapter further inquires about the extent to which former colonial powers rely on governmental actors for the distribution of aid, be it their own or by including recipient governments. Figure 7.2 shows the share of total aid (left panel) and social aid (right panel) being distributed through governmental channels. While patterns of government reliance are very similar for total and social aid, patterns between British and French aid diverge sharply. For both total and social aid, Britain relies much less on governmental channels, barely reaching $20 \%$ within its own former colonies. To the contrary, a majority of French aid is allocated 

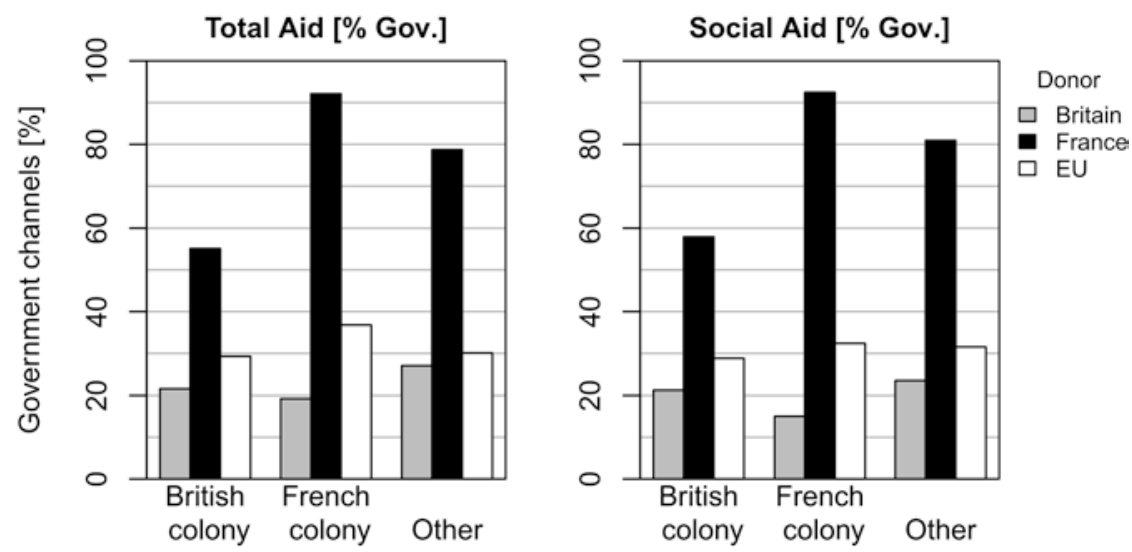

Fig. 7.2 Average annual aid flow by donor and colonial legacy, share disbursed through government channels (2007-2016)

through governmental channels. In its former colonies, the average government share exceeds $90 \%$, for total as well as social aid.

The descriptive figures lend some support to the above presented hypotheses. French aid to former colonies appears to be more reliant on governmental channels, and both donors provide higher shares of social aid to their own colonies, compared to colonies of the respectively other power (although not compared to other recipients). However, to determine whether these differences are not just coincidental or are confounded by other variables, I now turn to some more systematic tests of the hypotheses about colonial legacies in aid. Therefore, I estimate various linear models with different aid indicators as dependent variables. The main independent variable of interest is the colonial legacy of a dyad as well as its interaction with donor identity. Controls are included to account for potential confounding. The models are estimated by way of using a Bayesian Markov chain Monte Carlo (MCMC) approach, as this is better suited to situations where the sample constitutes the population and it is thus more meaningful to treat the data as fixed and the parameters as random (Western and Jackman 1994).

Bayesian models deviate from the standard frequentist approach in that they do not only provide a point estimate and standard error for each parameter but a complete posterior distribution. The mean of the 
distribution, here indicated as $b$, corresponds to the point estimate in frequentist statistics. Bayesian estimation usually refrains from strict null hypothesis testing. Instead one can infer the probability that a parameter is within a certain range directly from the posterior distribution. A helpful figure is the probability that the parameter is greater than zero, indicated here by $\%>0$. Values close to $100 \%$ indicate a very high probability that the parameter is greater than zero, whereas values close to $0 \%$ indicate a very high probability that the parameter is smaller than zero. Values not in the proximity of 0 or $100 \%$ indicate little or no evidence that the parameter is different from 0 . Analogously to conventional

Table 7.2 Linear model results: Total and social aid to former colonies

\begin{tabular}{|c|c|c|c|c|c|c|c|c|}
\hline \multirow{3}{*}{$\frac{\text { DV }}{\text { Model }}$} & \multicolumn{4}{|c|}{ Total aid [US \$m] } & \multicolumn{4}{|c|}{ Social aid [\% total] } \\
\hline & \multicolumn{2}{|l|}{ (1) } & \multicolumn{2}{|l|}{ (2) } & \multicolumn{2}{|l|}{ (3) } & \multicolumn{2}{|l|}{ (4) } \\
\hline & b & $\%>0$ & b & $\%>0$ & b & $\%>0$ & b & $\%>0$ \\
\hline Intercept & 0.38 & 99.50 & 18.68 & 98.80 & 31.96 & 100.00 & 32.40 & 100.00 \\
\hline Don & .48 & 17.50 & -2.72 & 36.80 & 10.01 & 99.50 & 9.31 & 97.80 \\
\hline Color & 47.55 & 100.00 & 52.83 & 100.00 & 9.23 & 98.40 & 8.08 & 92.30 \\
\hline $\begin{array}{l}\text { Donor: Fr.*Col. } \\
\text { Leg. }\end{array}$ & & & -13.70 & 20.00 & & & 2.56 & 60.80 \\
\hline GDP per capita & -2.58 & 1.60 & -2.72 & & .38 & 98 & 1.41 & 98.00 \\
\hline Pop & 0.09 & 100.00 & 0.09 & 100.00 & 0.02 & 90.80 & 0.02 & 91.30 \\
\hline Dem & -1.09 & 30.80 & -1.23 & 28.60 & 0.40 & 62.60 & 0.44 & 64.40 \\
\hline Trac & -0.26 & 0.70 & -0.26 & 0.60 & -0.12 & 2.00 & -0.12 & 1.5 \\
\hline & & & & & & & & \\
\hline Ameri & -10.02 & 20.30 & .30 & 19.10 & 6 & 30 & 17.74 & 0.40 \\
\hline & & & & 60.40 & 5 & 97 & 9.97 & 97.10 \\
\hline & 4.26 & 61.40 & 4.58 & 60.60 & 21.45 & 99.30 & 21.28 & 99.20 \\
\hline Oceania & -32.17 & 1.20 & -34.19 & 0.80 & -28.71 & 0.00 & -28.55 & 0.00 \\
\hline $\mathrm{R}^{2}$ & 0.328 & & 0.331 & & 0.254 & & 0.25 & \\
\hline$n$ & 222 & & 222 & & 222 & & 22 & \\
\hline
\end{tabular}

Note: Unit of observation is a donor-recipient dyad. Social aid [\% Total] indicates the share of total aid directed at social protection. Donor and Colonial legacy refer to the dyad, all other variables to the recipient: Income per capita in thousands (2011-US\$, PPP), Population size in millions, Trade openness indicates the trade share of GDP (in \%), Democracy ranges from -7 to -1 , the Continent reference category is Africa. All continuous explanatory variables are meancentered. $b$ indicates the mean of posterior distribution, $\%>0$ the share of posterior distribution greater than zero. MCMC estimation (Gibbs sampling, chain length $=1 \mathrm{~m}$, burn-in $=1 \mathrm{~m}$, thinning $=100$ ) 
null hypothesis testing, one might focus on whether $\%>0$ is within 2.5 percentage points of 0 or $100 \%$.

Table 7.2 presents the first model results. Models 1 and 2 both have the total amount of aid as dependent variable, with the difference that only the second model includes an interaction term between colonial legacy (which indicates the presence of an earlier colonial tie between donor and recipient) and donor identity (which takes the value 1 to indicate France, and 0 for Britain). Both models largely confirm the findings of earlier studies. Donors give more aid to their former colonies (an additional US $\$ 47.55$ million per year), more economically developed countries receive less aid and countries with larger populations receive more. While the parameter for the effect of democracy is unexpectedly negative, the evidence is very weak ( $\%>0$ close to 0.5$)$. Surprisingly, countries with greater trade openness appear to receive less aid, rather than being rewarded for it. The interaction term in Model 2 indicates that there are no substantial differences in how much aid both donors provide to former colonies.

The dependent variable in Models 3 and 4 is social aid as a share of total aid. In line with the first hypothesis, Model 3 indicates that the social protection share of aid to the respective donor's former colonies is about 9 percentage points higher than aid to other countries. Interestingly, the social protection share is positively related to income per capita, indicating that richer countries receive relatively more international support for investments in social protection. Model 4 further explores whether there are any differences between British and French aid. While the estimate of the interaction term points in the direction expected based on the second hypothesis, the evidence is too weak to be regarded as supporting the hypothesis.

The second set of models concerns the involvement of government actors in the distribution of bilateral aid. The dependent variable in Models 5 and 6 is the share of all aid distributed through governmental channels. Model 5 indicates a positive effect of colonial legacies on the involvement of government actors. However, the interaction effect of Model 6 shows that this effect is entirely driven by France's stronger reliance on governmental channels for disbursing aid to its former colonies. The colonial legacy parameter itself (main effect), which in this model represents the effect on British aid, is effectively reduced to zero. These 
results strongly support the third hypothesis about the reliance of French aid on governmental ties to former colonies.

Finally, Models 7 and 8 analyze colonial legacies in the share of social aid distributed through governmental channels. The results mirror those of the two previous models. The overall effect of colonial legacies is positive, but this is by and large due to France's higher reliance on governmental

Table 7.3 Linear model results: Aid disbursement through governmental channels

\begin{tabular}{|c|c|c|c|c|c|c|c|c|}
\hline \multirow{3}{*}{$\frac{\text { DV }}{\text { Model }}$} & \multicolumn{4}{|c|}{ Total aid [\% Gov.] } & \multicolumn{4}{|c|}{ Social aid [\% Gov.] } \\
\hline & \multicolumn{2}{|l|}{ (5) } & \multicolumn{2}{|l|}{ (6) } & \multicolumn{2}{|l|}{ (7) } & \multicolumn{2}{|l|}{ (8) } \\
\hline & $b$ & $\%>0$ & $\mathrm{~b}$ & $\%>0$ & $\mathrm{~b}$ & $\%>0$ & $\mathrm{~b}$ & $\%>0$ \\
\hline Intercept & 24.96 & 100.00 & 27.89 & 100.00 & 21.17 & 100.00 & 23.28 & 100.00 \\
\hline $\begin{array}{l}\text { Donor: } \\
\text { France }\end{array}$ & 50.78 & 100.00 & 45.12 & 100.00 & 55.69 & 100.00 & 51.65 & 100.00 \\
\hline $\begin{array}{c}\text { Colonial } \\
\text { legacy }\end{array}$ & 9.94 & 98.50 & 1.51 & 59.80 & 11.54 & 99.50 & 5.49 & 82.80 \\
\hline $\begin{array}{l}\text { Donor: } \\
\text { Fr. } * \text { Col. } \\
\text { Leg. }\end{array}$ & & & 20.69 & 98.70 & & & 14.76 & 94.60 \\
\hline $\begin{array}{l}\text { GDP per } \\
\text { capita }\end{array}$ & 1.07 & 93.20 & 1.27 & 96.20 & 0.95 & 91.10 & 1.09 & 94.00 \\
\hline $\begin{array}{l}\text { Population } \\
\text { size }\end{array}$ & 0.01 & 83.50 & 0.01 & 86.30 & 0.02 & 88.30 & 0.02 & 90.00 \\
\hline Democracy & -0.30 & 40.80 & -0.05 & 48.70 & -0.38 & 38.20 & -0.19 & 44.20 \\
\hline $\begin{array}{l}\text { Trade } \\
\text { openness }\end{array}$ & -0.18 & 0.20 & -0.18 & 0.20 & -0.17 & 0.20 & -0.18 & 0.20 \\
\hline Continent & & & & & & & & \\
\hline America & -23.51 & 0.10 & -23.46 & 0.10 & -21.79 & 0.10 & -21.78 & 0.10 \\
\hline Asia & 5.18 & 81.90 & 5.78 & 85.10 & 5.00 & 81.60 & 5.38 & 83.70 \\
\hline Europe & 12.57 & 91.40 & 11.78 & 89.90 & 15.33 & 95.40 & 14.75 & 94.60 \\
\hline Oceania & -34.04 & 0.00 & -31.61 & 0.00 & -32.40 & 0.00 & -30.71 & 0.00 \\
\hline $\mathrm{R}^{2}$ & 0.509 & & 0.520 & & 0.551 & & 0.557 & \\
\hline$n$ & 222 & & 222 & & 222 & & 222 & \\
\hline
\end{tabular}

Note: Unit of observation is a donor-recipient dyad. Total aid [\% Gov.] and Social aid [\% Gov.] indicate the share of total respectively social aid disbursed through governmental channels. Donor and Colonial legacy refer to dyad, all other variables to recipient: Income per capita in thousands (2011-US\$, PPP), Population size in millions, Trade openness indicates the trade share of GDP (in $\%)$, Democracy ranges from -7 to -1 , the Continent reference category is Africa. All continuous explanatory variables are mean-centered. $b$ indicates the mean of posterior distribution, $\%>0$ share of posterior distribution greater than zero. MCMC estimation (Gibbs sampling, chain length $=1 \mathrm{~m}$, burn-in $=1 \mathrm{~m}$, thinning $=100$ ) 
ties to former colonies. That being said, the estimate of the interaction term, about 15 percentage points, indicates a similar, if not smaller, difference between the two empires than that identified for total aid (circa 21 percentage points). As such, this result provides no support for the claim that the reliance on governmental channels diverges especially sharply for social aid to former colonies (fourth hypothesis) (Table 7.3).

\section{Discussion}

Due to the increasing availability of highly disaggregated and standardized data on aid flows, this chapter is able to draw a more nuanced picture of colonial legacies in international aid than earlier scholarship does. The well-established finding that colonial powers provide more bilateral aid to former colonies than to other countries was confirmed. In addition, I have demonstrated that a disproportionately large share of aid to former colonies supports social protection policies, funding activities related to health and education, amongst others. I have also shown that France, as it did during its colonial era, heavily relies on governmental actors to distribute aid. Instead, Britain relies to a much greater extent on nongovernmental actors and international organizations when it comes to disbursing aid.

The analysis conducted in this chapter provided no support for two of the hypotheses I presented in the beginning. While both Britain and France provide more aid for social protection in their former colonies, this pattern is not more pronounced in the French case. Compared to other countries, the share of aid supporting social protection is 9 percentage points higher for former colonies. Other than expected, I also found that France's stronger reliance on governmental actors is equally pronounced for aid aimed at social protection and for aid in total. As such, France does not rely particularly much on governmental actors when it comes to promoting social protection in its former colonies.

Although this chapter shows that certain colonial structures are reflected in contemporary patterns of bilateral aid, it does not elucidate the process underlying this continuity. The assumption of path dependencies, resulting from inertia in social, economic and political ties, for 
example, is certainly a meaningful starting point, but one that needs to be furthered explored. Equally important, one might wonder why bilateral aid carries no resemblance of other colonial structures. What, for example, happened to the unique approach to social protection in the French empire? Did France shed its goal to assimilate populations of (formerly) dependent territories? Does the success of international organizations, charities and civil society actors provide France with leeway to disburse aid through non-governmental channels despite its neglect of these actors during colonial times? Future research should also be concerned with such discontinuities. They constitute the "negative image" of continuities and are therefore just as important for understanding colonial legacies.

Shedding light on the processes underlying colonial legacies in international aid also needs to cope with questions about the motivations of donors to provide aid to former colonies. Earlier scholarship has employed various strategies to explore motivations for aid, mainly focusing on whether aid varied with contextual factors, either cross-sectionally or longitudinally. Some, for example, have analyzed whether aid goes to where it is most needed, for example low-income countries, or whether it complements donors' trade relationships. I have argued above that the social, economic and political ties that emerged under colonialism can affect the motivations of donors to provide aid. This argument finds support in the empirical evidence presented in this chapter, in particular the emphasis on social protection in aid to former colonies. This argument could be further probed by incorporating colonial legacies into existing crosssectional and longitudinal research strategies.

The emphasis in this chapter was on donors as external actors in LMICs and on how their engagement is defined by colonial legacies. Donors do, however, not operate within a vacuum. Their actions affect the strategies and behavior of other actors, domestic and external. And the actions of these other actors affect donors in turn. I have speculated about one example above, the multiplication of actors concerned with social welfare, which might be one reason why social protection practices by colonial France did not leave a lasting mark. National governments of recipient countries are another highly influential actor when it comes to the distribution of international aid. They assume a decisive role in the 
negotiation and coordination of aid packages, and just like in the case of donors, their strategies and bargaining positions are likely to carry a colonial imprint. As such, for understanding colonial legacies in international aid it is not sufficient to study only donors, but it is important to consider the constellation of actors and dynamics between them.

A final point refers to the generalizability of the presented findings. The analysis here has focused on the two largest and most recent colonial empires, Britain and France. How do the findings then apply to other colonial empires, such as those of Spain and Portugal, who controlled vast swaths of the world throughout the seventeenth and eighteenth centuries? What policies did they prioritize, what actor constellations did they promote and do colonial legacies prevail until today or have they been eroded over time? Exploring similarities and differences across and within colonial empires, and the duration of colonial legacies in international aid, are another avenue for future research.

\section{References}

Abernethy, David B. 2000. The Dynamics of Global Dominance: European Overseas Empires, 1415-1980. New Haven, CT: Yale University Press.

Alesina, Alberto, and David Dollar. 2000. Who Gives Foreign Aid to Whom and Why? Journal of Economic Growth 5 (1): 33-63.

Becker, Bastian. 2019. Introducing COLDAT: The Colonial Dates Dataset. Working Papers (2), SOCIUM/CRC1342.

Berthélemy, Jean-Claude, and Ariane Tichit. 2004. Bilateral Donors' Aid Allocation Decisions a Three-Dimensional Panel Analysis. International Review of Economics \& Finance 13 (3): 253-274.

Bodenstein, Thilo, and Achim Kemmerling. 2015. A Paradox of Redistribution in International Aid? The Determinants of Poverty-Oriented Development Assistance. World Development 76: 359-369.

Boschini, Anne, and Anders Olofsgård. 2007. Foreign Aid: An Instrument for Fighting Communism? The Journal of Development Studies 43 (4): 622-648. 
Cardoso, Fernando Henrique, and Enzo Faletto. 1979. Dependency and Development in Latin America. Trans. Mattingly Urquidi. Berkeley: University of California Press.

Daughton, J.P. 2013. ILO Expertise and Colonial Violence in the Interwar Years. In Globalizing Social Rights: The International Labour Organization and Beyond, ed. Sandrine Kott and Joelle Droux. Palgrave Macmillan: International Labour Office.

Deacon, Bob. 2007. Global Social Policy and Governance. Los Angeles and London: Sage Publications Ltd.

Dixon, John. 1989. A Comparative Perspective on Provident Funds: Their Present and Future Explored. Journal of International and Comparative Social Welfare 5 (2): 1-28.

Dollar, David, and Victoria Levin. 2006. The Increasing Selectivity of Foreign Aid, 1984-2003. World Development 34 (12): 2034-2046.

Easterly, William, and Tobias Pfutze. 2008. Where Does the Money Go? Best and Worst Practices in Foreign Aid. Journal of Economic Perspectives 22 (2): 29-52.

Freedom House. 2018. Freedom in the World 2017: The Annual Survey of Political Rights and Civil Liberties. Ed. A. Puddington. New York and Washington: Rowman \& Littlefield.

Fuchs, Andreas, Axel Dreher, and Peter Nunnenkamp. 2014. Determinants of Donor Generosity: A Survey of the Aid Budget Literature. World Development 56: $172-199$.

Gerring, John, Daniel Ziblatt, Johan Van Gorp, and Julian Arévalo. 2011. An Institutional Theory of Direct and Indirect Rule. World Politics 63 (3): 377-433.

Iliffe, John. 1987. The African Poor: A History, No. 58. Cambridge: Cambridge University Press.

Iyer, Lakshmi. 2010. Direct versus Indirect Colonial Rule in India: Long-term Consequences. The Review of Economics and Statistics 92 (4): 693-713.

Kpessa, Michael W. 2010. Ideas, Institutions, and Welfare Program Typologies: An Analysis of Pensions and Old Age Income Protection Policies in SubSaharan Africa. Poverty \& Public Policy 2 (1): 37-65.

Lahiri, Sajal, and Pascalis Raimondos-Møller. 2000. Lobbying by Ethnic Groups and Aid Allocation. The Economic Journal 110 (462): 62-79. 
Lee, Alexander, and Kenneth A. Schultz. 2012. Comparing British and French Colonial Legacies: A Discontinuity Analysis of Cameroon. Quarterly Journal of Political Science 7 (4): 365-410.

Lewis, Joanna. 2011. The British Empire and World History: Welfare Imperialism and 'Soft' Power in the Rise and Fall of Colonial Rule. In Colonialism and Welfare: Social Policy and the British Imperial Legacy, ed. J. Midgley and D. Piachaud, 17-35. Cheltenham, UK: Edward Elgar.

McKinlay, Robert D., and Richard Little. 1979. The US Aid Relationship: A Test of the Recipient Need and the Donor Interest Models. Political Studies 27 (2): 236-250.

Mamdani, Mahmood. 1996. Citizen and Subject: Contemporary Africa and the Legacy of Late Colonialism. Princeton, NJ: Princeton University Press.

Maul, Daniel Roger. 2007. The International Labour Organization and the Struggle against Forced Labour from 1919 to the Present. Labor History 48 (4): 477-500.

Midgley, James. 2011. Imperialism, Colonialism and Social Welfare. In Colonialism and Welfare: Social Policy and the British Imperial Legacy, ed. J. Midgley and D. Piachaud, 36-54. Cheltenham, UK: Edward Elgar.

Nunnenkamp, Peter, and Rainer Thiele. 2006. Targeting Aid to the Needy and Deserving: Nothing But Promises? The World Economy 29 (9): 1177-1201. OECD. 2010. DAC Statistical Reporting Directives. Accessed 7 February 2019. http://www.oecd.org/dac/stats/38429349.pdf.

- 2018a. Creditor Reporting System: Aid activities. OECD International Development Statistics. https://doi.org/10.1787/data-00061-en.

- 2018b. Geographical Distribution of Financial Flows to Developing Countries 2018: Disbursements, Commitments, Country Indicators. OECD. https://doi.org/10.1787/fin_flows_dev-2018-en-fr.

Pacquement, Francois. 2010. How Development Assistance from France and the United Kingdom Has Evolved: Fifty Years on from Decolonisation. International Development Policy | Revue internationale de politique de développement 1 (1): 51-75.

Pearson, Jessica Lynne. 2018. The Colonial Politics of Global Health: France and the United Nations in Postwar Africa. Cambridge, MA: Harvard University Press.

Pedersen, Susan. 2015. The Guardians: The League of Nations and the Crisis of Empire. Oxford; New York: Oxford University Press.

Round, Jeffery I., and Matthew Odedokun. 2004. Aid Effort and Its Determinants. International Review of Economics \& Finance 13 (3): 293-309. 
Schmitt, Carina. 2015. Social Security Development and the Colonial Legacy. World Development 70: 332-342.

Schraeder, Peter J., Steven W. Hook, and Bruce Taylor. 1998. Clarifying the Foreign Aid Puzzle: A Comparison of American, Japanese, French, and Swedish Aid Flows. World Politics 50 (2): 294-323.

Steinwand, Martin C. 2015. Compete or Coordinate? Aid Fragmentation and Lead Donorship. International Organization 69 (02): 443-472.

Suret-Canale, Jean. 1971. French Colonialism in Tropical Africa: 1900-1945. New York: Pica Press.

Wesseling, H.L. 2004. The European Colonial Empires, 1815-1919. Pearson/Longman.

Western, Bruce, and Simon Jackman. 1994. Bayesian Inference for Comparative Research. The American Political Science Review 88 (2): 412-423.

Woodberry, Robert D. 2012. The Missionary Roots of Liberal Democracy. American Political Science Review 106 (2): 244-274.

World Bank. 2018. World Development Indicators (WDI). Accessed 28 May 2018. https://datacatalog.worldbank.org/dataset/world-developmentindicators.

Open Access This chapter is licensed under the terms of the Creative Commons Attribution 4.0 International License (http://creativecommons.org/licenses/ by/4.0/), which permits use, sharing, adaptation, distribution and reproduction in any medium or format, as long as you give appropriate credit to the original author(s) and the source, provide a link to the Creative Commons licence and indicate if changes were made.

The images or other third party material in this chapter are included in the chapter's Creative Commons licence, unless indicated otherwise in a credit line to the material. If material is not included in the chapter's Creative Commons licence and your intended use is not permitted by statutory regulation or exceeds the permitted use, you will need to obtain permission directly from the copyright holder.

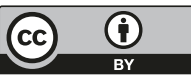

